\title{
COVID-19 RELATED DEVELOPMENT AID PROVIDED BY THE US AND THE RUSSIAN FEDERATION
}

\author{
() BELETSKAYA M.YU., 2021
}

\begin{abstract}
Maria Yu. BELETSKAYA, Cand. Sci. (Econ.), Researcher, Center for Sectoral Studies. Institute for the U.S. and Canadian Studies, Russian Academy of Sciences (ISKRAN), 2/3 Khlebny per., Moscow 121069, Russian Federation (mybeletskaya@gmail.com), ORCID: 0000-0003-3141-6052.
\end{abstract}

Beletskaya M.Yu. COVID-19 Related Development Aid Provided by the US and the Russian Federation. Analysis and Forecasting. IMEMO Journal, 2021, № 4, cc. 58-71. DOI: 10.20542/afij-2021-4-58-71

DOI: $10.20542 / a f i j-2021-4-58-71$

УДК: $339.9(4)$

Received 21.10.2021.

Accepted 03.11.2021.

The outbreak of the pandemic of COVID-19 in 2020 affected all spheres of human life and reiterated the important role of international development cooperation. This paper provides a qualitative study of the international assistance by the United States and Russian Federation as active donors and suppliers of vaccines against the COVID-19 virus. The research is based on publications in scientific journals, as well as up-to-date information on the official websites of U.S. and Russian government agencies related to the provision of such assistance. In addition, publications of aggregated data on the fight against the spread of coronavirus are used. The results indicate that in spite of a large gap between the U.S. and Russia's development aid volumes, the political ambitions and actual objectives of development aid policies are similar. The initial response to the pandemic was similar between both countries. However, as the situation developed, the attitude towards vaccination and subsequently providing vaccine doses as aid proved to be different between the U.S. and Russia. While the U.S. concentrated heavily on the vaccination of its own population, Russia made an emphasis on using its vaccine as a "soft power" on the international market.

Keywords: International Development Cooperation, International Assistance, Donor Country, Aid Recipient, Sustainable Development Goals, U.S., Russia, COVID-19 pandemic, "soft power".

For decades, the international development assistance carried out by developed countries pursued a wide range of goals, such as finding the solution of humanitarian and economic issues of the recipient countries, as well as ambitions related to the economic and political interests of donor countries. Questions concerning development aid are widely reflected in works by A. Sen [1], P. Rosenstein-Rodan [2], Alesina A. and Dollar D. [3], and others. The United States retains its place as the world's first donor in terms of official development assistance, and has been providing development assistance for many decades. Russia, having gone through a transition period to a market economy, when it was a recipient of Western aid, has recently entered the global donor pool. The scale of Russian international development aid is smaller than that of the United States. At the same time, the unique situation created by the COVID-19 pandemic has opened up a window of opportunity for Russian aid to set off the large-scale promotion of Russian interests in dozens of countries around the world. Development and distribution of COVID-19 vaccines can be viewed as an expression of "soft power", a concept introduced into academic circulation by J.S. Nye [4]. 
Currently, there are a large number of publications dealing with a variety of vaccination issues around the world. These works examine the medical, logistic, economic and political aspects of these processes, often highlighting the inequalities in vaccine distribution [5]. At the same time, a relatively small number of articles are devoted to a comparative analysis of approaches to international assistance in terms of vaccination from different countries. Assistance by the United States, generally, is compared with the aid programs of China ${ }^{1}$, as one of the most significant economic competitors - see, for example, B.M. Boylan, J. McBeath and B. Wang [6]; M. Ye [7]; S.S.F. Regilme Jr. and O. Hodzi [8]. Exploration of Russian approaches to COVID-19 related aid receives less attention and is usually presented as a part of broader surveys $[9 ; 10]$.

Only minor attention is paid to the analysis of the approaches to international assistance in terms of vaccination against COVID-19 in countries with different economic scales, but relatively great political ambitions. This article aims to fill a gap in analytical studies that compare the US and Russian approaches to international vaccination assistance. In particular, the article shows the possibilities of achieving significant results using "soft power" with relatively few resources.

This is a qualitative study of the international assistance by the United States and Russia as active donors and suppliers of vaccines against the novel coronavirus COVID-19. The research is based on publications in scientific journals, as well as up-to-date information on the official websites of US and Russian government agencies related to the provision of such assistance. In addition, online publications of media and other portals that aggregate data on the fight against the spread of coronavirus are used. This approach allows one to obtain a relatively holistic picture of US and Russian assistance and formulate comparative conclusions.

The article is structured as follows: first, the situation with the spread of COVID-19 in the world and the scale of vaccination are discussed. Then the approaches to international assistance in terms of vaccination from the United States are considered and attention is paid to Russian international vaccination policy and the use of the Sputnik V vaccine. The article ends with a comparative discussion of the different approaches to aid and results of the US and Russian policies, with subsequent conclusions.

\section{CURRENT COVID-19 SITUATION IN THE WORLD}

The outbreak of the COVID-19 pandemic in 2020 affected all spheres of human life and reiterated the important role of international development cooperation in the "back to normal" efforts.

Globally, as of 30th September 2021, there have been $233,136,147$ confirmed cases of COVID-19, including 4,771,408 deaths, as reported to World Health Organization (WHO). As of 29th September 2021, a total of 6,136,962,861 vaccine doses have been administered ${ }^{2}$.

The spread of the pandemic has intensified most of the challenges faced by both development aid donor and recipient countries, adding to them a major global component: the need to combat the pandemic, revise living and working standards to prevent future pandemics, and the need to develop a new mechanism for economic growth. The mechanism of international assistance, which has been tested for decades, with all its shortcomings and problems, is used to solve these problems and to support the development of individual countries. Its use for the formation of mechanisms that respond to global challenges presupposes actions in various directions (economic, social, technological, environmental, foreign policy, etc.).

\footnotetext{
${ }^{1}$ Christensen T.J. A Modern Tragedy? COVID-19 and US-China Relations. Foreign Policy at Brookings, May 2020. 9 p. Available at: https://www.brookings.edu/wp-content/uploads/2020/05/FP 20200511 covid us china christensen v3.pdf (accessed 10.10.2021).

${ }^{2}$ WHO Coronavirus (COVID-19) Dashboard. Available at: https://covid19.who.int/ (accessed 05.10. 2021).
} 
The United Nations Conference on Trade and Development (UNCTAD) estimates that the speed of the pandemic's impact on developing economies has been even more "dramati" than during the 2008 financial crisis ${ }^{3}$. In the two months since the outbreak of the coronavirus, developing countries have been hit hard by capital outflows, higher government debt interest rates, falling currencies and lost export earnings. The consequences of the pandemic and the global recession will be catastrophic for many developing countries and stop their progress towards the SDGs. The crisis is undermining sources of revenue that developing countries can use to combat the consequences of the pandemic.

The economic crisis triggered by the pandemic has caused an alarming growth of anxiety and depression levels all over the world ${ }^{4}$. The pandemic has been especially hard for young people. Reduced social contacts and transition to distant learning can have a lasting effect on children and young adult plans and prospects. The Organisation for Economic Cooperation and Development (OECD) survey confirms that people are worried about jobs, finances and their future, and $44 \%$ of households reported having at least one member whose work had been disrupted by the crisis 5 . People are also worried about the loss of income and as a consequence decreasing affordability of long-term care services for their family members. The regional and local impact of the COVID-19 crisis is highly heterogeneous and requires policies aimed at the creation of more resilient regions.

The pandemic negatively affected both the US and Russian economies. In 2020, GDP in these countries decreased by $3.5 \%$ and $3 \%$, respectively ${ }^{6}$. The negative impact on the Russian economy was relatively less significant due to the nature of its structure. The main blow of the pandemic in the world fell on small and medium-sized enterprises (SME). The share of SMEs in Russian GDP in 2019 was about $21 \%{ }^{7}$, while in the United States it is estimated at about $44 \%[11]$.

It should be noted that in both United States and Russian Federation, during the first phase of the pandemic, its future negative impact was not perceived as a serious national and global threat. However, the increase in the number of infected and number of deaths, the huge burden on health systems have led to the need for urgent restrictive measures and the development of vaccines.

Vaccination is one of the core measures to combat the spread of the pandemic. Currently, the distribution of vaccines is concentrated mostly in developed countries and this contributes to regional inequalities. The redistribution of vaccines through the development cooperation channels is becoming a priority.

At the same time, a huge gap in vaccination rates between developed and low-income countries remains. As of the end of September 2021, $44.5 \%$ of the world population has received at least one dose of a COVID-19 vaccine. Globally, 6.13 billion doses have been administered, and 24.98 million are now administered each day. Only $2.2 \%$ of people in lowincome countries have received at least one dose ${ }^{8}$.

3 The Covid-19 Shock to Developing Countries: Towards a "Whatever it Takes" Programme for the Two-Thirds of the World's Population Being Left Behind. UNCTAD. Available at: https://unctad.org/system/files/official-document/gds tdr2019 covid2 en.pdf (accessed 20.05.2021).

${ }^{4}$ Tackling the Mental Health Impact of the COVID-19 Crisis: An Integrated, Whole-of-Society Response. OECD Policy Responses to Coronavirus (COVID-19). OECD. 12.05.2021. Available at: https://www.oecd.org/coronavirus/policyresponses/tackling-the-mental-health-impact-of-the-covid-19-crisis-an-integrated-whole-of-society-response-0ccafa0b/? $g a=2.247652930 .416353729 .1620814785-2066025542.1539248784$ (accessed 30.05.2021).

${ }^{5}$ Risks that Matter 2020: The Long Reach of COVID-19. OECD Policy Responses to Coronavirus (COVID-19). OECD. 28.04.2021. Available at: https://www.oecd.org/coronavirus/policy-responses/risks-that-matter-2020-the-long-reach-ofcovid-19-44932654/ (accessed 07.05.2021).

${ }^{6}$ GDP Growth (annual \%). World Bank. Available at: https://data.worldbank.org/indicator/NY.GDP.MKTP.KD.ZG?view=chart (accessed 07.10.2021).

${ }^{7}$ TheShareofSmallandMedium-SizedBusinessesinthe GrossDomesticProductoftheRussianFederation. FederalStateStatistics Service. 2021. Available at: https://rosstat.gov.ru/storage/mediabank/NIGSWSzi/\%D0\%94\%D0\%BE\%D0\%BB\%D1\%8F\%20 \%D0\%9C\%D0\%A1\%D0\%9F\%20\%D0\%B2\%20\%D0\%92\%D0\%92\%D0\%9F\%20(\%D1\%81\%202017\%20\%D0\%B3.).xIsX (accessed 10.10.2021).

${ }^{8}$ Coronavirus Pandemic (COVID-19). OurWorld in Data. Available at: https://ourworldindata.org/coronavirus (accessed 10.10.2021). 
Not only low-income countries are suffering. The summarized estimate presented in the paper by Çakmaklı, et al. [12] shows that up to $49 \%$ of the global economic costs of the pandemic in 2021 are borne by the advanced economies, even if they achieve universal vaccination in their own countries. A fair and more equitable distribution of vaccines is not simply charity but is economically justified. The losses in developed countries may be greater than the costs of producing vaccines and organizing vaccinations in recipient countries.

One of the responses to the global nature of vaccination problems were international measures to accelerate the development and production of vaccines, as well as the COVAX mechanism (COVID-19 Vaccines Global Access Facility) formed by WHO in early 2020, designed to ensure access to vaccines for countries in need of them [13]. However, solving the problem of access to vaccines in countries that do not produce them is complicated by "vaccine nationalism": that is, the priority in vaccination of the population of developed countries that produce vaccines and purchase excessive doses [14]. The fairness of the vaccine distribution mechanism is also being discussed [15].

Successfully implementing assistance policies in the yet to be fully vaccinated donor countries is influenced by the attitude of their own population towards vaccination. A recent study by J.S. Solís Arce et al. [10] based on fairly broad surveys of the population of different countries that asked the question «If a COVID-19 vaccine becomes available in [country], would you take it?» shows positive responses in the United States (mean 64.6\%) are almost 2 times higher than in Russia (mean 30.4\%). This attitude relatively limits the possibilities of aid or vaccine export for the United States, in contrast to Russia. It is important to note that in low- and middle-income countries (LMICs) in Asia, Africa and South America, the interest in vaccination is much higher - the average percentage of positive answers to the question is $80.3 \%$ (mean $80.3 \%$; median $78 \%$; range 30.1 percentage points). These results are close to other similar studies. For example, the Ipsos survey for The World Economic Forum, prepared by January $2021^{9}$, indicates that according to the results of population surveys in 15 countries, a positive answer to the question "If a vaccine for COVID-19 were available to me, I would get it?" in Russia was given only in $42 \%$ of cases, which is less than in all other countries. Moreover, in the United States, a positive response was received in $71 \%$ of cases.

\section{AID PROVIDED BY THE UNITED STATES}

The United States has been providing international assistance on an ongoing basis since the Second World War and currently is the largest donor with more than $\$ 35$ billion in official development assistance provided in $2020^{10}$.

In the U.S. the international development aid is regulated by Foreign Assistance Act ${ }^{11}$, adopted in 1961. This act outlines key principles of aid provision and contains the definition of international development aid. At the same time, the Agency for International Development (USAID), a specialized parent organization for the provision of international assistance, was created.

The United States is involved in providing aid to more than a hundred countries around the world with more than 20 US government agencies participating in this process. The largest volumes of aid are directed to the Middle East and Africa. In addition, assistance is being provided to other developing countries in Asia and Latin America ${ }^{12}$.

\footnotetext{
${ }_{9}^{9}$ Global Attitudes on a COVID 19 Vaccine. (2021). Ipsos Survey for the World Economic Forum. Available at: https://www.ipsos. com/sites/default/files/Global-attitudes-on-a-COVID-19-Vaccine-January-2021-report\%20.pdf (accessed 10.10.2021).

${ }^{10}$ Total Flows by Donor (ODA+OOF+Private). OECD.Stat. Available at: https://stats.oecd.org/Index.aspx?DataSetCode=TABLE1 (accessed 01.06.2021).

11 Foreign Assistance Act of 1961. U.S. Congress House. Available at: $h$ ttps://www.foreign.senate.gov/imo/media/doc/ Foreign\%20Assistance\%20Act\%200f\%201961.pdf (accessed 07.05.2021).

12 U.S. Foreign Assistance by Agency. Available at: https://foreignassistance.gov/agencies (accessed 01.10.2021).
} 
In 2016, to ensure the effectiveness of the aid system, the Foreign Aid Transparency and Accountability Act was adopted ${ }^{13}$. The main objectives of the U.S. development aid are poverty alleviation, sustainable economic growth of the recipient countries and improvements in recipient countries' governments.

In recent years the United States provided non-military assistance to countries in areas such as economic development, environmental protection, humanitarian aid, the promotion of democratic principles and the protection of human rights, health care, education and social protection, ensuring the maintenance of peace and stability of countries, technical assistance and others (see Table 1, compiled according to the USAID methodology). Each of these areas includes various types of assistance.

In total, there are more than 50 types of assistance identified in the U.S. statistics. Some types of assistance are provided only to specific countries, while others are a part of global projects, covering a significant number of countries.

Table 1. U.S. Foreign Assistance Volume by Assistance Categories, billion \$US

\begin{tabular}{|l|c|c|c|}
\hline & $\mathbf{2 0 1 9}$ & $\mathbf{2 0 2 0}$ & $\mathbf{2 0 2 1}^{*}$ \\
\hline Foreign Assistance, total & 34.7 & 34.1 & 6.6 \\
\hline Humanitarian Assistance & 8.52 & 5.6 & 1.6 \\
\hline Health & 7.36 & 7.37 & 2.83 \\
\hline Multi-sector & 4.15 & 5.03 & 0.1 \\
\hline Peace \& Security & 4.48 & 5.54 & 0.1 \\
\hline Economic Development & 3.43 & 3.86 & 0.6 \\
\hline Program Management & 3.14 & 3.15 & 0.6 \\
\hline Education and Social Services & 1.44 & 1.36 & 0.3 \\
\hline Democracy, Human Rights and Governance & 1.75 & 1.62 & 0.3 \\
\hline Environment & 0.5 & 0.5 & 0.08 \\
\hline
\end{tabular}

* Data as of 01.06.2021.

Source: compiled by the author on USAID data ${ }^{14}$.

Since the emergence of the coronavirus disease (COVID-19) in early 2020, the United States Agency for International Development (USAID) has worked in partnership with the U.S. Department of State (DoS), the National Security Council (NSC), and others to lead the U.S. Government's global response, track the spread of the outbreak, and direct assistance to affected countries.

In the aftermath of the COVID-19 outbreak, the U.S. government announced more than US $\$ 1.5$ billion in emergency health, humanitarian, economic, and development assistance from the Department of State and the USAID, specifically targeting helping governments, international organizations and others fight the pandemic. This funding, provided by the U.S. Congress, is used to improve health education; protect medical institutions; and build laboratory capacity, surveillance and rapid response in over 120 countries.

The aid objectives in response to COVID-19 were to provide emergency relief, strengthen health systems, support vaccine readiness and distribution, improve public health education, protect healthcare workers and facilities.

On March 27, 2020, Secretary Michael R. Pompeo said that "Whenever you see high quality, effective COVID-19 aid being delivered around the world by UN humanitarian and relief agencies, what you are seeing is the generosity of the American people and those who share our humanitarian values"15.

\footnotetext{
${ }^{13}$ Foreign Aid Transparency and Accountability Act of 2016 Public Law 114-191. July 15, 2016. U.S. Government Publishing Office. Available at: https://uscode.house.gov/statutes/pl/114/191.pdf (accessed 07.05.2021).

${ }^{14}$ See: U.S. Foreign Assistance by Sector. 2021. Available at: $h$ ttps://www.foreignassistance.gov/ (accessed 01.06.2021).

15 U.S. Role in International Organizations' Response to COVID-19. U.S. Embassy in Argentina. Available at: https://ar.usembassy.gov/u-s-role-in-international-organizations-response-to-covid-19/ (accessed 10.05.2021).
} 
The U.S., through USAID, has contributed US $\$ 2$ billion to Global Alliance for Vaccines and Immunisation (GAVI), the Vaccine Alliance, to support the purchase and delivery of COVID-19 vaccines to 92 low- and middle-income countries, and plans to commit another $\$ 2$ billion by $2022^{16}$.

However, along with the expansion of U.S. assistance to counter the pandemic, there are global border closures and restrictions on movement both between and within countries, making it difficult to implement ongoing assistance projects. It can be assumed that the provision of technical assistance, which is associated with the participation of American specialists in the implementation of projects in recipient countries, is difficult. At the November 21-22, 2020 summit of the G20 countries, participants, including Donald Trump, signed a declaration in which the countries confirmed their readiness to continue the fight against the COVID-19 pandemic ${ }^{17}$. Countries also confirmed that they will continue to support all developing and least developed countries in the fight against the pandemic, especially in Africa and small island states.

At the same time, the United States did not support the UN initiative to join COVAX (the international system for the distribution of the COVID-19 vaccine) under the Trump administration. The United States joined COVAX on January 20, 2021, almost 10 months after the initiative started. The first contribution made by the United States on 19 February, consisted of US\$ 4 billion ${ }^{18}$.

As of mid-2021, the overwhelming majority of vaccines produced in the United States is used to vaccinate their own population and are not provided as assistance ${ }^{19}$. Vaccine nationalism in the United States had good reasons. If earlier problems with epidemics caused serious difficulties, primarily in low-income countries, the coronavirus pandemic hit developed countries, primarily the United States, hard. In the early May of 2020, an American was dying of COVID-19 every forty-nine seconds. The U.S., with $4 \%$ of the world's population, had more than 30\% of the sick [16]. Speaking on March 11, 2021, President Biden said the coronavirus has killed more than half a million Americans. That's more deaths than in World War One, World War Two, the Vietnam War, and 9/11 combined $^{20}$. In 2020, the United States faced unprecedented difficulties with its health care system, and only by the middle of next year the situation began to stabilize, with technical and political restrictions on the deployment of vaccination assistance to other countries being eased.

The United States planned to donate a total of 80 million doses of the Pfizer Inc (PFE.N)/ BioNTech SE, Moderna Inc (MRNA.O) and Johnson \& Johnson (JNJ.N) vaccines by the end of June, $2021^{21}$.

Biden Administration announced its framework for sharing these 80 million U.S. vaccine doses worldwide. Specifically, the United States committed to sharing $75 \%$ of these vaccines through COVAX and the rest $25 \%$ would go for immediate needs and help with surges around the world. For doses shared through COVAX, the United States prioritized Latin America and

16 USAID to Provide Initial \$2 Billion to Propel Global Access to COVID-19 Vaccines. Statement by Acting Administrator Gloria Steele. 19.02.2021. Available at: $h$ ttps://www.usaid.gov/news-information/press-releases/feb-19-2021-usaid-provide-initial-2billion-propel-global-access-covid-19 (accessed 07.05.2021).

17 Leader's Declaration G20 Riyadh Summit. November 21-22, 2020. Available at: https://www.ilo.org/wcmsp5/groups/ public/@dgreports/@dcomm/documents/meetingdocument/wcms 761761.pdf (accessed 20.05.2021).

${ }^{18}$ Biden to Pledge \$4 Billion to COVAX Vaccine Program at G7 Meeting Friday. Reuters, 19.02.2021. Available at: $\underline{h t t p s: / /}$ www.reuters.com/article/us-usa-biden-covax-idUSKBN2AI2YP (accessed 20.09.2021).

19 Ghosh J. Covid-19: Vaccine Production and Distribution Has Exposed - and Intensified - Global Inequality. Scroll. in, 2021. Available at: https://scroll.in/article/992328/covid-19-vaccine-production-and-distribution-has-exposed-andintensified-global-inequality (accessed 20.05.2021).

${ }^{20}$ Remarks by President Biden on the Anniversary of the COVID-19 Shutdown. The White House. March 11, 2021. Available at: https://www.whitehouse.gov/briefing-room/speeches-remarks/2021/03/11/remarks-by-president-biden-on-the-anniversaryof-the-covid-19-shutdown/ (accessed 30.05.2021).

${ }^{21}$ U.S. Will Donate Substantial Portion of Vaccines through COVAX-U.S. Official. Reuters, 19.05.2021. Available at: $\underline{h t t p s: / /}$ www.reuters.com/world/us/us-will-donate-substantial-portion-vaccines-through-covax-us-official-2021-05-19/ (accessed 20.05.2021). 
the Caribbean, South and Southeast Asia, and Africa, in coordination with the African Union ${ }^{22}$.

On August 3, it was announced that the U.S. has now donated and shipped more than 110 million doses of its COVID-19 vaccines to more than 60 countries. The majority of these vaccines - made in the United States - were shipped through COVAX.

Starting at the end of August, the Administration began shipping half a billion Pfizer doses that the United States has pledged to purchase and donate to 100 low-income countries in need, over fulfilling their initial plan ${ }^{23}$.

With an increase in vaccine production and a high rate of vaccination, the problem of "vaccine nationalism" in the United States has diminished. As of the end of October 2021 the US distributes vaccines to about 60 countries and has already shipped over 225 million doses, not counting those distributed through COVAX ${ }^{24}$.

U.S. positions itself as a leader in the fight against the pandemic, with President Biden pledging that U.S. will be the world's arsenal for vaccines ${ }^{25}$. The "USAID Implementation Plan for the U.S. COVID-19 Global Response and Recovery Framework" states that U.S. will continue to play a leading role in global vaccination efforts tin order to build back a stronger, more resilient global community ${ }^{26}$.

\section{AID PROVIDED BY THE RUSSIAN FEDERATION}

Russia's participation in international development assistance began in 1992 after the collapse of the USSR, when Russia inherited the commitments of the USSR as a donor country, including packages of agreements signed by the USSR with other countries, as well as the debts of these countries to the USSR. Large-scale assistance to developing countries was provided by the USSR since the 1950s.

The first years after the collapse of the USSR and the transition to a market economy forced Russia to start intensive borrowing. The amounts received as international aid and borrowed were very significant. At the same time, Russia tried to settle the inherited debts of other countries and even provide symbolic assistance to countries facing natural disasters.

This situation began to change after the 1998 economic crisis, which became a turning point for the economic development of Russia. The default and devaluation of the ruble played a role. The rise in oil prices also helped kick-start Russia's economic recovery. Political conditions have emerged in parallel with the development of the economic prerequisites for international development assistance. By this time, ideas about the role and place of Russia in the global international aid system began to take shape, and the corresponding documents were prepared.

\footnotetext{
${ }^{22}$ FACT SHEET: Biden-Harris Administration Unveils Strategy for Global Vaccine Sharing, Announcing Allocation Plan for the First 25 Million Doses to be Shared Globally. The White House. June 03, 2021. Available at: https://www.whitehouse.gov/ briefing-room/statements-releases/2021/06/03/fact-sheet-biden-harris-administration-unveils-strategy-for-global-vaccinesharing-announcing-allocation-plan-for-the-first-25-million-doses-to-be-shared-globally/ (accessed 20.09.2021).

${ }^{23}$ Fact Sheet: President Biden Announces Major Milestone in Administration's Global Vaccination Efforts: More Than 100 Million U.S. COVID-19 Vaccine Doses Donated and Shipped Abroad. The White House. August 03, 2021. Available at: $h$ ttps://www. whitehouse.gov/briefing-room/statements-releases/2021/08/03/fact-sheet-president-biden-announces-major-milestone-inadministrations-global-vaccination-efforts-more-than-100-million-u-s-covid-19-vaccine-doses-donated-and-shipped-abroad/ (accessed 20.09.2021).

24 Vaccine Donations. Launch and Scale Speedometer. Available at: https://launchandscalefaster.org/covid-19/ vaccinedonations (accessed 01.11.2021).

25 Commemorating 200 Million U.S.-Donated COVID-19 Vaccines Successfully Delivered. Statement by Administrator Samantha Power. USAID. October 21, 2021. Available at: https://www.usaid.gov/news-information/press-releases/oct-212021-commemorating-200-million-us-donated-covid-19-vaccines-successfully (accessed 01.11.2021).

26 USAID Implementation Plan for The U.S. COVID-19 Global Response and Recovery Framework. USAID. October 18, 2021. Available at: https://www.usaid.gov/coronavirus/usaid-implementation-plan-covid-global-response-recovery-framework (accessed 01.11.2021).
} 
Since 2005, Russia has been formally excluded by the OECD from the list of countries receiving assistance.

This stage of Russia's involvement in the international development assistance system ended in June 2007 with the adoption of the Concept of Russia's participation in international development assistance ${ }^{27}$. From 2008 to 2014 approximately $90 \%$ of Russian aid was provided through international organizations.

In April 2014, by the decree of the President of the Russian Federation, the Concept of the State Policy of the Russian Federation in the field of international development assistance was approved ${ }^{28}$. Since then, Russia has been steadily developing as a new donor country while shifting from providing multilateral aid towards primarily bilateral approach.

There is no specialized government aid organization in Russia, although the creation of one has been discussed. Until recently, most of assistance related questions were solved by government agencies including Rossotrudnichestvo. In November 2020, a decree of the President of the Russian Federation ${ }^{29}$ was issued on the creation of an Interdepartmental Commission for International Development Assistance. This commission is headed by the Deputy Chief of Staff of the Presidential Administration of the Russian Federation. As before, decisions on international aid are made outside the public space, in particular, they are not discussed in the parliament. Official figures on aid are not published, but the Russian Ministry of Finance has been sending selected indicators on international development aid to the OECD, where they have been published since 2010.

According to data provided by Russia to the OECD, official development assistance in 2020 amounted to US\$ 1 billion ${ }^{30}$.

The distribution of aid by sector (compiled according to the OECD methodology) is provided in Table 2.

Table 2. Russia's Official Development Assistance by Sector, US Dollar, Millions

\begin{tabular}{|l|c|c|c|}
\hline \multicolumn{1}{|c|}{ Year } & 2018 & 2019 & 2020 \\
\hline Sector & \multicolumn{2}{|c|}{} \\
\hline I. Social Infrastructure \& Services & 54.67 & 92.03 & 93.45 \\
\hline I.1. Education & 8.96 & 5.52 & 3 \\
\hline I.2. Health & 34.93 & 44.46 & 68.94 \\
\hline I.3. Population Policies/Programmes \& Reproductive Health &.. & 5.47 & 5.84 \\
\hline I.4. Water Supply \& Sanitation &.. &.. & 2.22 \\
\hline I.5. Government \& Civil Society & 5.48 & 25.81 & 13.44 \\
\hline II. Economic Infrastructure \& Services & 9.7 & 3.2 & 1.66 \\
\hline III. Production Sectors & 12.03 & 4.64 & 13.8 \\
\hline IV. Multi-Sector / Cross-Cutting & 66.49 & 42.04 & 20.7 \\
\hline V. Total Sector Allocable (I+II+III+IV) & 142.89 & 141.91 & 129.61 \\
\hline VI. Commodity Aid / General Programme Assistance & 42.73 & 111.32 & 122.25 \\
\hline VII. Action Relating to Debt & 424.94 & 424.93 & 424.94 \\
\hline
\end{tabular}

\footnotetext{
${ }^{27}$ Russia's Participation in International Development Assistance. 2007. Available at: https://www.minfin.ru/common/img/ uploaded/library/2007/06/concept eng.pdf (accessed 15.04.2021).

${ }^{28}$ Concept of the Russian Federation's State Policy in the Area of International Development Assistance, 2014. Available at: https://www.mid.ru/en/foreign policy/official documents/-/asset publisher/Cpt/CkB6BZ29/content/id/64542 (accessed 15.04.2021).

29 Decree of the President of the Russian Federation of 05.11.2020 No. 676 On the Interdepartmental Commission for International Development Assistance. (In Russ.) Available at: http://www.kremlin.ru/acts/bank/45998 (accessed 20.09.2021).

30 OECD.Stat. Table: Total flows by donor (ODA+OOF+Private). Available at: https://stats.oecd.org/Index. aspx?DataSetCode=TABLE1 (accessed 1.06.2021)
} 


\begin{tabular}{|l|c|c|c|}
\hline VIII. Humanitarian Aid & 15.48 & 14.73 & 18.18 \\
\hline IX. Unallocated / Unspecified & 2.11 & 0 & 2.02 \\
\hline Total (V+VI+VII+VIII+IX) & 628.15 & 692.89 & 697 \\
\hline
\end{tabular}

Source: compiled by the author on OECD.Stats ${ }^{31}$.

At the same time, in 2019, federal budget spending on international relations and international cooperation as indicated in Russia's budget was 3.77 billion US\$, and in 2020 it grew to 4.99 billion US\$ (at the official exchange rate), which may serve as an indirect sign of an increase in international aid spending in $2020^{32}$. Unfortunately, Russia does not provide more official in-depth data to better understand what kinds of aid were provided.

Since the beginning of the pandemic, several reports were published giving estimates on COVID-19 related aid provided by Russia.

According to a recent study of the Center for Advanced Governance [17], as of August 2, 2020, Russia has provided assistance in the fight against coronavirus to at least 46 countries, mainly through bilateral channels. In terms of geography, Russian aid was distributed as follows:

- the priority region for Russia was that of the close neighboring countries, especially the Commonwealth of Independent States (CIS), primarily the republics of Central Asia, Armenia and Belarus. The delivery of humanitarian aid to the population of southeastern Ukraine is also included, although official Kiev did not apply to Russia for humanitarian aid;

- in Europe, Bosnia and Herzegovina, Italy, Moldova and Serbia received Russian assistance;

- in the Middle East and North Africa, Russia helped Algeria, Iran, Lebanon and Syria, as well as Afghanistan, which borders on the region;

- in the Western Hemisphere, Russian aid recipients were states in South America (Brazil and Venezuela), Central America and the Caribbean (Guatemala, Dominican Republic, Costa Rica, Cuba, Nicaragua, Panama, El Salvador) and the U.S.;

- in Sub-Saharan Africa, Russia helped Guinea, the Democratic Republic of the Congo, Djibouti, Namibia, Senegal, South Africa and Sierra Leone;

- in Southeast Asia Russia provided aid to Indonesia, Cambodia, Laos and Myanmar;

- in Oceania Russia assisted Nauru.

Despite the fairly wide geographical coverage, it should be noted that in a number of cases Russian aid was small in volume and demonstrative. For example, to help the United States, an airplane was sent with a load of ventilators, which, due to technical reasons, were never used ${ }^{33}$. However, as a diplomatic gesture with manifestation of "soft power", it was deemed effective [18].

In addition to bilateral assistance, Russia has allocated additional funds to counter the coronavirus and through multilateral channels in the form of financial contributions:

- to the Trust Fund "Russian Federation - United Nations Development Program for Development" (UNDP) up to US\$ 6 million $^{34}$;

- to the International Committee of the Red Cross (ICRC) 500 thousand Swiss francs ${ }^{35}$;

- to the WHO up to US\$ 1 million ${ }^{36}$.

${ }^{31}$ See: OECD.Stats. 2021. Available at: https://stats.oecd.org/ (accessed 01.11.2021).

32 Federal Budget. The Federal Treasury. (In Russ.) 2021. Available at: https://roskazna.gov.ru/ispolnenie-byudzhetov/ federalnyj-byudzhet/ (accessed 15.04.2021).

${ }^{33}$ Taylor M., Stolyarov G. Exclusive: Russian Ventilators Reached U.S. States without FDA Oversight. Reuters, 22.05.2020. Available at: https://Www.reuters.com/article/us-health-coronavirus-usa-ventilators-ex-idUSKBN22Y2F4/ (accessed 20.04.2021).

34 Press Release on Signing the Memorandum on the Replenishment of the Russia-UNDP Trust Fund for Development. Available at: https://www.mid.ru/programma-razvitia-oon-proon-/-/asset publisher/Zuc5DeW1p/7y/content/id/4134673 (accessed 20.04.2021).

${ }^{35}$ Order of the Government of the Russian Federation dated 28.05.2020 No. 1415-p. (In Russ.) Available at: http://publication. pravo.gov.ru/Document/View/0001202006010009 (accessed 20.04.2021).

${ }^{36}$ Order of the Government of the Russian Federation dated 03.04.2020 No. 863-p. (In Russ.) Available at: http://publication. pravo.gov.ru/Document/View/0001202004060017 (accessed 20.04.2021). 
The specific purpose of these funds (in addition to the general wording "to fight the new coronavirus infection") is not publicly disclosed at this stage and remains the subject of agreement between the donor and recipient. Typically, these financial flows are earmarked and project-oriented, as opposed to regular contributions. It should be noted that the volumes of such contributions by Russia to international organizations for specific humanitarian purposes greatly exceed the regular financial obligations.

Russia's annual contribution to the WHO budget is about US $\$ 6$ million, and to the ICRC and UNDP - about 1 million Swiss francs and US $\$ 1$ million respectively. Recent examples of targeted contributions not related to coronavirus include the decision of the Government of the Russian Federation to contribute up to US \$9 million to WHO in three tranches until 2022 to "implement measures to assist countries to improve the quality of medical care provided in hospitals, with the aim of reducing maternal, newborn and child mortality and accelerating the achievement of health targets under the Sustainable Development Goals". The already mentioned contribution to the UNDP trust fund envisages the transfer of an additional USD 24 million in 2021-2023 "in order to ensure the participation of the Russian Federation in the global efforts to implement the 2030 Sustainable Development Agenda".

Russia promotes Sputnik V vaccine as the world's first registered vaccine. The vaccine was registered by the Russian Ministry of Health in August 2020. Subsequent studies and publications in the Lancet magazine confirmed its effectiveness and safety, however, the haste with registration and an aggressive information campaign caused a certain degree of mistrust [19]. Two other vaccines were approved by the Russian government for emergency use: EpiVacCorona, produced by the Vector Institute in Novosibirsk, and CoviVac, from the Chumakov Centre in St Petersburg.

At the same time, it is noted that the characteristics of the Sputnik V vaccine allow it to be widely used in countries with middle and low incomes. The relatively low price, transportation and storage conditions meet the needs of such countries. With this in mind, many countries have expressed interest in using this vaccine and it is registered in more than 70 countries [20].

Vaccine supplies in the form of assistance are still small, mainly on a commercial basis or transfer of technology for its production. According to Russian data, Russia cooperates with more than 14 countries in the production of the vaccine, and in more than 50 countries it is used for vaccination ${ }^{37}$.

UNICEF has signed an agreement with Human Vaccine, a subsidiary of the Russian Direct Investment Fund, for supply of up to 220 million doses of Sputnik V vaccine ${ }^{38}$. However, whether or not the promise will be fulfilled depends on when Sputnik V will receive emergency use listing from the World Health Organization, in order to fully participate in COVAX initiative. Russia has applied for participation in March 2021 $1^{39}$. In October 2021, after checks carried out by WHO and a meeting with its representatives, the Russian Minister of Health announced the removal of barriers to vaccine registration ${ }^{40}$. At the same time, the president of the Argentine pharmaceutical company Richmond Laboratories, which produces the Sputnik V vaccine, Marcelo Figueiras, said that WHO would register this vaccine within 1-2 months ${ }^{41}$. The long period of review of the Sputnik V vaccine by WHO officials is connected not only with objective problems but also with the politicization of the situation around the Russian vaccine.

\footnotetext{
${ }^{37}$ Partnership for Producers. Spuntik V. 2021. Available at: https://sputnikvaccine.com/partnerships/(accessed 20.10.2021). ${ }^{38}$ UNICEF Signs Supply Agreement for Sputnik V COVID-19 Vaccine. Available at: $h$ ttps://www.unicef.org/press-releases/unicefsigns-supply-agreement-sputnik-v-covid-19-vaccine (accessed 30.05.2021).

39 Russia Applied for Participation of Sputnik V Vaccine in COVAX. TASS, 23.03.2021. Available at: $\underline{h t t p s: / / t a s s . c o m / ~}$ economy/1269389/ (accessed 10.04.2021).

${ }^{40}$ Murashko Said that All Barriers to Registration of "Sputnik V" in WHO Have Been Removed. TASS, 02.10.2021. (In Russ.) Available at: https://tass.ru/obschestvo/12562613/ (accessed 10.10.2021).

${ }^{41}$ Figueiras estimó que "en uno o dos meses" la Sputnik V será aprobada por la OMS. Télam, 01.10.2021. Available at: $\quad$ https://www.telam.com.ar/notas/202110/570369-figueiras-estimo-que-en-uno-o-dos-meses-la-sputnik-v-podria-seraprobada-por-la-oms.html (accessed 10.10.2021).
} 
Russia has announced about the distribution of 1.5 million vaccine doses as aid, which will be provided to about ten countries. As of the end of October 2021, these plans were fulfilled by $36 \%$ and 532500 doses were delivered ${ }^{42}$.

Vaccine production is also gradually increasing. According to the Russian Minister of Industry and Trade, 40 million doses of Sputnik V vaccine were produced in September 2021, and about 150 million more doses are planned to be released by the end of the year ${ }^{43}$.

On the whole, Russia has shown itself to be a country capable of rapidly developing vaccines and organizing their production. This increased the respect for the country [21], although there were certain problems with the organization of mass production and the supply of the vaccine.

According to experts [22], in 2020, COVID-19 related aid has become one of the most important facets of Russian soft power with a potential to strengthen international contacts and develop a positive image in Asia, Latin America and Africa. This applies not only to regions, but also specific countries, such as Serbia [23].

Despite the large differences between the United States and Russian Federation in economic potential and their approaches to providing assistance, several similarities between their views and positions can be distinguished: the perception of the threat of a pandemic in its initial phase, difficulties in scaling up vaccine production and the wary attitude of the population of countries towards their vaccination.

In both United States and Russia, as well as the rest of the world, information about the beginning of the epidemic in China was not perceived as a global or national threat [24], which would later require not only efforts to combat it within the country but also global efforts and international assistance to other countries. However, this perception was quickly replaced by a transition to the implementation of measures to contain and combat the virus, an understanding of the global nature of the problem and the importance of helping other countries.

For almost the first time in modern history, the virus has dealt a serious blow to developed countries, and the question about the priorities for the distribution of vaccines within and between countries arose. Here, the approaches of the United States and Russia were quite different. The United States, first of all, organized the vaccination of its citizens, and only after reaching a certain level of vaccination, began the large-scale deliveries of the vaccine abroad. In Russia, due to different mechanisms for making decisions on supplies and international aid, the problem of "vaccine nationalism" was not so acute. On the contrary, there have been extensive efforts to promote the vaccine to other countries. The major limitations here were technical difficulties preventing a sharp increase in vaccine production.

Data indicated the difference in attitude towards vaccination readiness in the United States (approximately $2 / 3$ of the population) and in Russia (approximately $1 / 3$ of the population). Note that as of early October 2021, the proportion of fully and fully and partially vaccinated in the United States was 55\% and 64\%, and in Russia - 29\% and 33\% ${ }^{44}$. Thus, it can be said with a certain degree of accuracy that everyone who would have liked to be vaccinated has been vaccinated. Although the level of vaccination in Russia cannot be considered sufficient, the achievement of such indicators opens up even more opportunities for the supply of vaccines to other countries.

\footnotetext{
42 See: Vaccine Donations... Op. cit.

${ }^{43}$ Manturov Spoke about Plans to Produce Vaccines Against Coronavirus. RIA News, 04.10.2021. (In Russ.) Available at: https://ria.ru/20211004/vaktsiny-1752947685.html (accessed 10.10.2021).

${ }^{44}$ Coronavirus (COVID-19) Vaccinations. Our World in Data. 2021. Available at: $\underline{\text { https://ourworldindata.org/covid-vaccinations }}$ (accessed 10.10.2021).
} 
The United States leads the world in the number of doses of vaccine delivered as aid, with most of the aid being channeled through the COVAX program, thus confirming its position as the largest donor of aid programs. Russian Federation still does not participate in the COVAX program due to the lack of registration of the vaccine by the WHO and supplies the vaccine for export and as assistance on a bilateral basis. Russia confirmed its status as a country with scientific and technological potential for the development and production of vaccines. Despite the existing restrictions, the Russian vaccine has already been approved for use and is being used in an impressive number of countries, and its foreign production has begun. Although vaccine aid supplies are still small, such positive response from a large number of other countries expands the potential for the use of "soft power", and helps with forming the image of a technologically advanced donor country.

With COVID-19 becoming a new constant, an effective and efficient global vaccine policy is one of the major factors that will determine how soon the pandemic will be contained. Success in producing and distributing vaccines to countries in need is becoming an important component in determining the status for countries producing vaccines.

\section{REFERENCES}

1. Sen A. The Man without a Plan: Can Foreign Aid Work? [Review of the White Man's Burden: Why the West's Efforts to Aid the Rest Have Done so Much III and so Little Good by W. Easterly]. Foreign Affairs, 2006, no. 85(2), pp. 171-177. DOI: $10.2307 / 20031920$

2. Rosenstein-Rodan P. International Aid for Underdeveloped Countries. The Review of Economics and Statistics, 1961, no. 43 (2), pp. 107-138. DOI: 10.2307/1928662

3. Alesina A., Dollar D. Who Gives Foreign Aid to Whom and Why? Journal of Economic Growth, 2000 , no. 5 (1), pp. 33-63. DOI: 10.1023/A:1009874203400

4. Nye J.S. Soft Power: the Evolution of a Concept. Journal of Political Power, 2021, vol. 14, iss. 1, pp. 196 208. DOI: $10.1080 / 2158379 X .2021 .1879572$

5. Su Z., McDonnell D., Li X., Bennett B., Šegalo S., Abbas J., Cheshmehzangi A., Xiang Y.T. COVID19 Vaccine Donations - Vaccine Empathy or Vaccine Diplomacy? A Narrative Literature Review. Vaccines, 2021, no. 9 (1024). DOI: 10.3390/vaccines9091024

6. Boylan B.M., McBeath J., Wang B. US-China Relations: Nationalism, the Trade War, and COVID-19. Fudan Journal of the Humanities and Social Sciences, 2021, vol. 14, pp. 23-40. DOI: 10.1007/s40647020-00302-6

7. Ye M. The COVID-19 Effect: US-China Narratives and Realities. The Washington Quarterly, 2021, no. 44 (1), pp. 89-105. DOI: 10.1080/0163660X.2021.1893513

8. Regilme Jr. S.S.F., Hodzi, O. Comparing US and Chinese Foreign Aid in the Era of Rising Powers. The International Spectator, 2021, no. 56 (2), pp. 114-131. DOI: 10.1080/03932729.2020.1855904

9. Natsios A.S. Foreign Aid in an Era of Great Power Competition. PRISM, 2020, no. 8 (4), pp. 100-119.

10. Solís Arce J.S., Warren S.S., Meriggi N.F., Scacco A., McMurry N., Voors M., Omer S.B. COVID-19 Vaccine Acceptance and Hesitancy in Low-and Middle-Income Countries. Nature Medicine, 2021, no. 27 (8), pp. 1385-1394. DOI: 10.1038/s41591-021-01454-y

11. Highfill T., Cao R., Schwinn R., Prisinzano R., Leung D. Measuring the Small Business Economy. BEA Working Paper Series, 2020, iss. WP2020-4. Available at: https://www.bea.gov/index.php/system/files/ papers/BEA-WP2020-4 0.pdf (accessed 10.10.2021).

12. Çakmaklı C., Demiralp S., Kalemli-Özcan S., Yeşiltaş S., Yıldırım M.A. The Economic Case for Global Vaccinations: An Epidemiological Model with International Production Networks. Cambridge, National Bureau of Economic Research, 2021. Available at: https://www.nber.org/system/files/working papers/ w28395/w28395.pdf (accessed 10.10.2021). DOI: 10.3386/w28395

13. Eccleston-Turner M., Upton H. International Collaboration to Ensure Equitable Access to Vaccines for COVID-19: The ACT-Accelerator and the COVAX Facility. The Milbank Quarterly, 2021, vol. 99, no. 2 pp. 426-449. DOI: 10.1111/1468-0009.12503

14. Rutschman A.S. Is There a Cure for Vaccine Nationalism? Current History, 2021, vol. 120, iss. 822, pp. 9-14. DOI: 10.1525/curh.2021.120.822.9

15. Sharma S., Kawa N., Gomber A. WHO's Allocation Framework for COVAX: Is It Fair? Journal of Medical Ethics, March, 2021. Available at: https://jme.bmj.com/content/medethics/early/2021/04/08/ medethics-2020-107152.full.pdf (accessed 10.10.2021). DOI: 10.1136/medethics-2020-10715

16. Sternfeld J., Egan T. Unrepared. America in the Time of Coronavirus. New York, Bloomsbury Publishing, 2020. $384 \mathrm{p}$.

17. Шакиров О., Петросян М., Соловьев Д. Гуманитарная помощь против коронавируса. Кому и как помогала Россия во время пандемии COVID-19? Центр перспективных управленческих решений. 2020. [Shakirov O., Petrosyan M., Soloviev D. Humanitarian Aid Against Coronavirus: To Whom And How Did Russia Help During the COVID-19 Pandemic. Center for Advanced Governance. 2020. (In Russ.)] Available at: https://cpur.ru/research pdf/russian-anti-covid-aid-2020.pdf (accessed 07.04.2021).

18. Артамонова У.3. Пандемия COVID-19: вызовы и возможности для публичной дипломатии России 
и США. США и Канада: экономика, политика, культура, 2021, № 6, сc. 89-110. [Artamonova U. COVID-19 Pandemic: Challenges and Opportunities for Russian and American Public Diplomacy. USA \& Canada: Economics, Politics, Culture, 2021, no. 6, pp. 89-110. (In Russ.)] DOI: 10.31857/ S268667300015221-3

19. Baraniuk C. Covid-19: What Do We Know about Sputnik V and Other Russian Vaccines? BMJ, 19.02.2021. Available at: https://www.bmj.com/content/372/bmj.n743.full.pdf (accessed 04.04.2021). DOI: 10.1136/bmj.n743

20. Cazzola M., Rogliani P., Mazzeo F., Matera M.G. Controversy Surrounding the Sputnik V Vaccine. Respiratory Medicine, 2021, vol. 187. 6 p. Available at: https://www.ncbi.nlm.nih.gov/pmc/articles/ PMC8352655/pdf/main.pdf (accessed 20.09.2021). DOI: 10.1016/j.rmed.2021.106569

21. Ferry L., O'Brien-Udry C. Turning the Tables? Aid, Status and Stability in the International System. The Political Economy of International Organization. 30.01.2021. Available at: https://www.peio.me/wpcontent/uploads/2021/papers/PEIO021 paper 67.pdf (accessed 10.10.2021).

22. Бурлинова Н., Чагина М., Иванченко В. Публичная дипломатия России в эпоху COVID-19. Ежегодный обзор основных трендов и событий публичной дипломатии России в 2020 г. Российский совет по международным делам, Центр поддержки и развития общественных инициатив “Креативная дипломатия". 2021. 38 p. [Burlinova N., Chagina M., Ivanchenko V. Public Diplomacy of Russia in the Era of COVID-19. Annual Review of the Main Trends and Events in Russian Public Diplomacy in 2020. Russian Council for International Affairs (RIAC), Center for Support and Development of Public Initiatives "Creative Diplomacy". 2021. 38 c. (In Russ.)] Available at: https://russiancouncil.ru/papers/ RussianPublicDiplomacyCOVID-Report71-Rus.pdf (accessed 07.04.2021).

23. Великая А.А. Роль гуманитарной помощи в позиционировании страны на примере зарубежного содействия Сербии в борьбе с COVID-19. Обозреватель-Observer, 2020, № 7 (336), сс. 53-63. [Velikaya A. The Humanitarian Aid in Nation Branding. The Case of Foreign Assistance to Serbia in the Fight against COVID-19. Obozrevatel'-Observer, 2020, no. 7 (336), pp. 53-63. (In Russ.)]

24. Дынкин А.А., Телегина Е.А. Шок пандемии и посткризисный мир. Мировая экономика и международные отношения, 2020, т. 64, № 8, cc. 5-16. [Dynkin A., Telegina E. Pandemic Shock and the World After Crisis. Mirovaya ekonomika i mezhdunarodnye otnosheniya, 2020, vol. 64, no. 8, pp. 5-16. (In Russ.)] DOI: 10.20542/0131-2227-2020-64-8-5-16 


\section{РОССИЙСКАЯ И АМЕРИКАНСКАЯ ПОМОЩЬ РАЗВИТИЮ В СВЯЗИ С COVID-19}

\section{(Анализ и прогноз. Журнал ИМЭМО РАН, 2021, no. 4, pp. 58-71)}

\section{Статья поступила в редакцию 21.10.2021. Статья принята редакцией 03.11.2021.}

БЕЛЕЦКАЯ Мария Юрьевна (mybeletskaya@gmail.com), ORCID: 0000-0003-3141-6052. Институт США и Канады Российской академии наук (ИСКРАН), РФ, 121069 Москва, Хлебный переулок, д. 2/3.

Пандемия COVID-19 в 2020 2. затронула все сферы жизни человека и подтвердила важную роль международного сотрудничества в челях развития. В данной статье представленоисследованиемеждународной помощи состороныСоединенныхШтатов Америки и Российской Федерации в качестве активных доноров и поставщиков вакцин против COVID-19. Исследование основано на публикациях в научных журналах, а также на актуальной информачии на офичиальных сайтах государственных органов США и России, связанной с оказанием такой помощи. Кроме того, используются публикачии агрегированных данных по борьбе с распространением коронавирусной инфекиии. Результаты исследования показывают, что несмотря на большой разрыв между объемами помощи в челях развития США и России, политические амбичии и фактические чели политики помощи обеих стран схожи. Первоначальная реакция на пандемию была также одинаковой. Однако по мере развития ситуации отношение к вакциначии и последующему предоставлению доз вакцины в качестве помощи оказалось различным в США и России. Соединенные Штаты в значительной степени сосредоточились на вакцинации своего населения, а Россия сделала акцент на использовании своей вакцины в качестве "мягкой силы" на международном рынке.

Ключевые слова: Международное сотрудничество в иелях развития, Международная помощь, "мягкая сила", Цели устойчивого развития, США, Россия, пандемия COVID-19.

Об авторе:

БЕЛЕЦКАЯ Мария Юрьевна, кандидат экономических наук, научный сотрудник, Центр прикладных экономических исследований.

DOI: 10.20542/afij-2021-4-58-71 